\title{
Comparison of the effect of recycled crumb rubber and polymer concentration on the performance of binders for asphalt mixtures
}

\author{
A. Jiménez del Barco-Carrión $\bowtie$, G. García-Travé, F. Moreno-Navarro, \\ G. Martínez-Montes, M.C. Rubio-Gámez \\ Construction Engineering Laboratory of the University of Granada (Granada, Spain) \\ \ajbc@ugr.es
}

Received 15 October 2015

Accepted 12 January 2016

Available on line 13 July 2016

\begin{abstract}
Crumb rubber modified binders are environmental-friendly alternatives to polymer modified bitumens in asphalt mixtures. This paper compares the performance of both types of binders with different modifier contents. Six binders were characterised by conventional tests and analysed using the UCL method. This method evaluates different properties of binders regarding their role in asphalt mixtures (cohesion, water and thermal sensitivity and resistance to ageing). Results showed that i) crumb rubber concentration has to be higher than that of SBS-polymers in order to obtain a similar performance to that of SBS-polymer modified bitumen; ii) crumb rubber modified binders are more stable than SBS-polymer modified binders in terms of modifier concentration; iii) crumb rubber modified binders exhibited less water sensitivity and similar thermal and ageing susceptibility to SBS-polymer modified binders; iv) linear relationships have been found between modifier concentration and the properties studied for both kind of binders.
\end{abstract}

KEYWORDS: Bitumen; Polymer; Weathering; Adherence; Characterisation

Citation/Citar como: Jiménez del Barco-Carrión, A.; García-Travé, G.; Moreno-Navarro, F.; Martínez-Montes, G.; Rubio-Gámez, M.C. (2016) Comparison of the effect of recycled crumb rubber and polymer concentration on the performance of binders for asphalt mixtures. Mater. Construcc. 66 [323], e090. http://dx.doi.org/10.3989/mc.2016.08815.

RESUMEN: Comparación del efecto de la concentración de polvo de neumático reciclado y polímeros en el comportamiento de ligantes para mezclas bituminosas. Los betunes modificados con polvo de neumático (PN) son alternativas ambientalmente sostenibles a los betunes modificados con polímeros. Este artículo compara el comportamiento de ambos tipos de betunes con varios contenidos de modificador. Para ello, se caracterizaron seis betunes mediante ensayos convencionales y método UCL. Este método evalúa propiedades de ligantes para su uso en mezclas bituminosas (cohesión, sensibilidad al agua, térmica y al envejecimiento). Los resultados muestran que i) la concentración de PN ha de ser más elevada que la de polímeros para obtener comportamiento semejante; ii) los betunes con PN son más estables ante cambios en la concentración de modificador que los betunes con polímeros; iii) los betunes con PN presentan menor sensibilidad al agua y equivalente susceptibilidad térmica y al envejecimiento que los betunes con polímeros; iv) se encontraron buenos ajustes lineales entre la concentración de modificadores y la evolución de las propiedades estudiadas.

PALABRAS CLAVE: Betún; Polímero; Envejecimiento; Adherencia; Caracterización

Copyright: (C) 2016 CSIC. This is an open-access article distributed under the terms of the Creative Commons Attribution License (CC BY) Spain 3.0. 


\section{INTRODUCTION}

The use of polymers as binder modifiers in asphalt mixtures is currently a common practice in pavement engineering, patented since 1843. Over the last few decades, the addition of these materials, chains of repeated small molecules, to bitumen has shown great improvements in its performance. Pavements with polymer modification exhibit greater resistance to rutting and thermal cracking, and decreased fatigue damage, stripping, plastic deformations and temperature susceptibility $(1,2)$.

However, because of the increase of environmental requirements, other alternative modifiers have been developed to obtain high performance, environmentally sustainable binders (3). From among the different options, recycled crumb rubber has shown great potential to be an effective alternative to polymers in pavement engineering $(1,4)$. In general, the addition of crumb rubber to bitumen increases its viscosity and elasticity, obtaining binders that are more resistant to rutting, fatigue and thermal cracking. However, there are different parameters that affect the final performance of crumb rubber modified (CRM) binders. In this way, authors have shown that the concentration of modifier is an essential parameter to control since it exerts a significant effect on storage stability, viscosity and rheology of the binder (5-9).

Although the influence of the concentration of modifiers has been studied in those different aspects, the research described in this paper provides a new approach to the subject, focusing on the analysis of the most important engineering properties of binders for asphalt mixtures: cohesion, water, thermal and ageing sensitivity. These properties have been studied by means of the UCL (Universal de Caracterización de Ligantes) method. This method was developed by the Road Research Laboratory in the Transportation Department at the Technical University of Catalonia in 1994 to characterize binders (10) and its reliability has been extensively proven by different researchers in studies such as those related to the cohesion of CRM binder (11) or bituminous mix ageing $(12,13)$. Thereby, conventional tests and the UCL method have been applied to three SBS-polymer modified binders and three CRM binders with different concentrations of modifiers and their comparison has been carried out.

\section{MATERIALS AND METHODS}

\subsection{Materials}

In order to analyse the influence of the concentration of modifiers in crumb rubber-modified binder (CRMB) and SBS polymer-modified binder (PMB), three CRMB and three PMB with different modifier concentrations were studied. In order to have representative results to compare the behaviour of both modifiers, both types of binder had the same base bitumen (50/70 penetration grade). Then, starting with an initial concentration of modifiers (PMB-1 and CRMB-1), each concentration was reduced in the same percentage in both binders, with the reduction being 30\% (PMB-2 and CRMB-2) and 75\% (PMB-3 and CRMB-3). Table 1 shows the percentage of each modifier on each binder.

In the UCL method, binders are mixed with a particular mineral skeleton. This mineral skeleton consists of a gap-graded gradation with a maximum aggregate size of $5 \mathrm{~mm}$ to highlight the effect of the binder (Figure 1). The same type of aggregates was used during the development of the whole research: ophite with resistance to fragmentation (14) of $22 \%$ (less than $25 \%$ is required for the UCL method) and absorption (15) of $1.28 \%$ (less than $1.5 \%$ is required for the UCL method). All UCL samples had the same binder content $(4.3 \%)$ and voids in mix $(26 \pm 2 \%)$ (Table 2$)$. These requirements were specially defined by (10) to emphasize binder properties in the tests and assess their influence (i.e. all the variables were the same for all the samples with the exception of the type of binder).

TABLE 1. Concentration of modifier on each binder by weight of bitumen

\begin{tabular}{lc}
\hline Bitumen & Modifier concentration (\%) \\
\hline PMB-1 & 3.75 \\
PMB-2 & 2.63 \\
PMB-3 & 1.31 \\
CRMB-1 & 5.0 \\
CRMB-2 & 3.5 \\
CRMB-3 & 1.75 \\
\hline
\end{tabular}

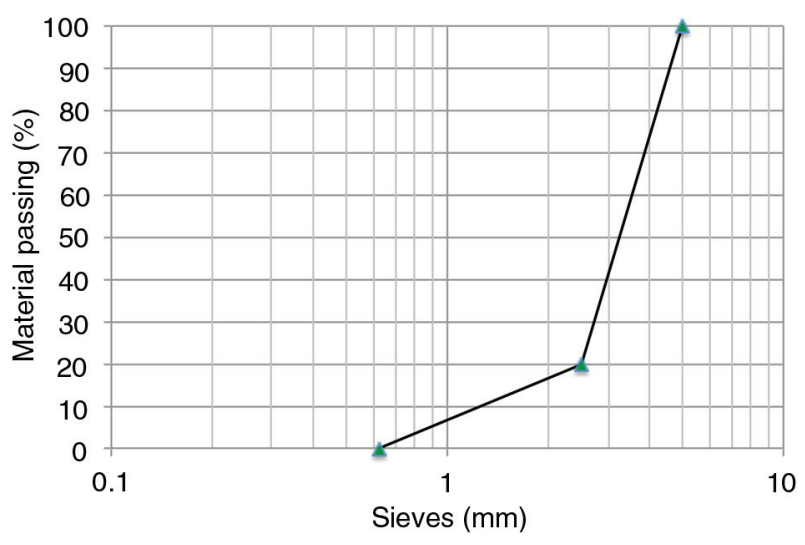

FIGURE 1. UCL aggregate grain-size curve. 
TABLE 2. UCL samples properties

\begin{tabular}{lcccc}
\hline Bitumen & Bitumen Content, (\%) & Bulk Density, $\mathbf{M g} / \mathbf{m}^{\mathbf{3}} \mathbf{( 1 6 )}$ & Voids in $\mathbf{m i x}, \mathbf{\%}(\mathbf{1 7})$ & Voids in aggregates (\%) (17) \\
\hline PMB-1 & 4.3 & 1.987 & 25.1 & 33.4 \\
PMB-2 & 4.3 & 1.988 & 25.1 & 33.4 \\
PMB-3 & 4.3 & 1.975 & 25.9 & 34.1 \\
CRMB-1 & 4.3 & 2.013 & 24.1 & 32.5 \\
CRMB-2 & 4.3 & 1.996 & 24.8 & 33.1 \\
CRMB-3 & 4.3 & 1.976 & 25.6 & 33.8 \\
\hline
\end{tabular}

\subsection{Methods}

The effect of modifier content on the PMBs and CRMBs was studied and compared through the conventional characterisation of the binders and the UCL method.

\subsubsection{Bitumen characterization}

Penetration test at $25^{\circ} \mathrm{C}(18)$, determination of softening point (19), determination of Fraass breaking point (20), viscosity at $140{ }^{\circ} \mathrm{C}$, elastic recovery at $25{ }^{\circ} \mathrm{C}(21)$ and force-ductility test at $25{ }^{\circ} \mathrm{C}(22)$ were undertaken to characterise all bitumens.

\subsubsection{UCL method}

The UCL method studies the behaviour of asphalt binders in terms of cohesion of the binder, water, thermal and ageing sensitivity (10). The method is based on the Cantabro test (23).

The Cantabro test consists of testing a Marshall specimen (24) in Los Angeles machine and exposing it to the abrasion test without steel balls. In this research, the number of revolutions of Los Angeles machine was fixed at 200. After the abrasion, the weight loss of each particular specimen is calculated in a percentage, in relation to the initial weight. Cantabro losses are considered to represent the amount of cohesion imparted by the binder to the mix (13). The UCL method changes the conditions

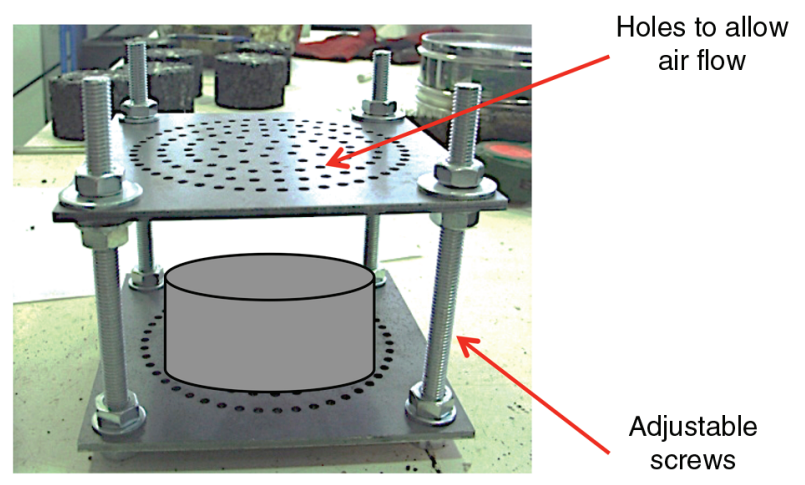

FIGURE 2. Device for ageing process. to which the specimens are submitted before the Cantabro test to evaluate each property.

Cohesion was assessed by keeping the specimens at $25{ }^{\circ} \mathrm{C}$ for 24 hours and submitting them to the Cantabro test (dry set). After that, water sensitivity was evaluated by measuring the increase of the Cantabro losses of the dry set when it is kept immersed in water at $60{ }^{\circ} \mathrm{C}$ for 24 hours (wet set). Thermal sensitivity was assessed by studying the variations of the Cantabro losses of the standard mix with temperature. For this purpose, specimens were conditioned at $25^{\circ} \mathrm{C}, 10^{\circ} \mathrm{C}$ and $-10{ }^{\circ} \mathrm{C}$ for 12 hours before being tested. Finally, to evaluate the ageing resistance, the mix was exposed to different ageing conditions and compared with the standard one. Specimens were kept in a convection oven at $163{ }^{\circ} \mathrm{C}$ for 2 hours, 4 hours and 8 hours respectively before being tested. The Cantabro test was always performed at $25^{\circ} \mathrm{C}$.

During the ageing process, specimens could suffer deformations and losses of material as well as runoff of the binder to the lower part of the sample due to the high temperature. In order to avoid the former, specimens were laterally confined by a wire mesh with a mesh size big enough to allow the hot air circulation but small enough to avoid material losses. However, to minimize the runoff of the bitumen, specimens were located in a special device which consists of two plates full of holes and joined by screws (Figure 2) which allows the position of the specimen to be manually reversed and thus avoiding the concentration of bitumen in a specific area of the specimen. The device was reversed every 2 hours.

\section{RESULTS AND DISCUSSION}

Results have been analysed in two different ways: (1) comparing the performance of PMB and CRMB; (2) assessing the influence of the concentration of modifiers in both binders.

\subsection{Performance of modified binders}

\subsubsection{Conventional tests}

Figure 3 (a-f) shows the results of conventional binder characterization for the different modifier concentrations. In order to compare the 

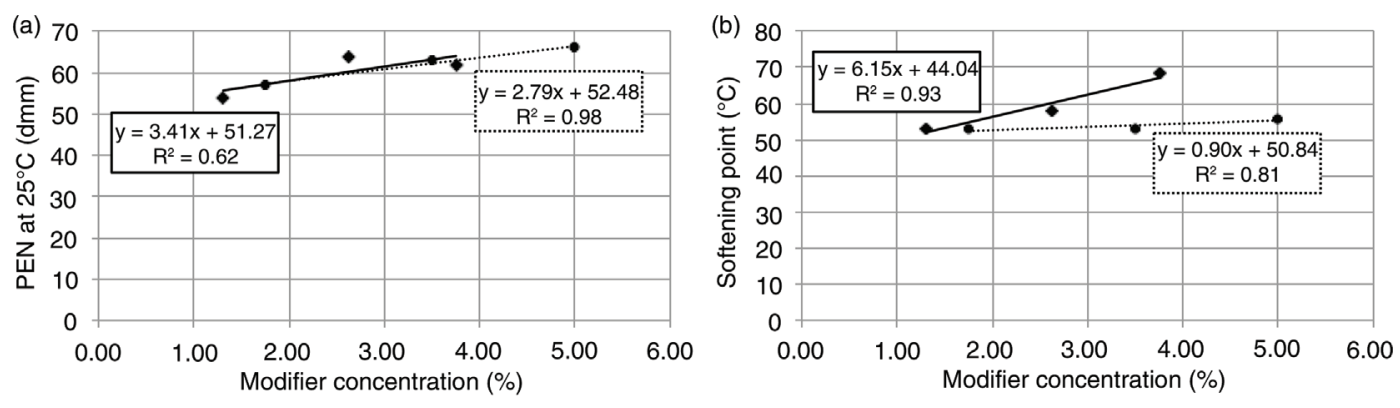

$\bullet \mathrm{PMB} \bullet \mathrm{CRMB}$

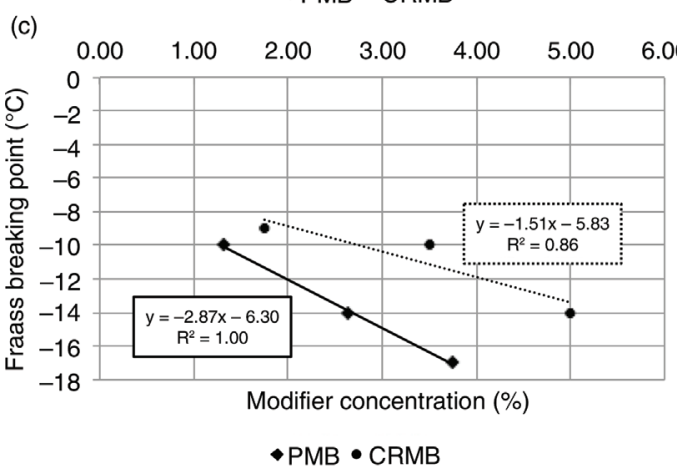

(d)
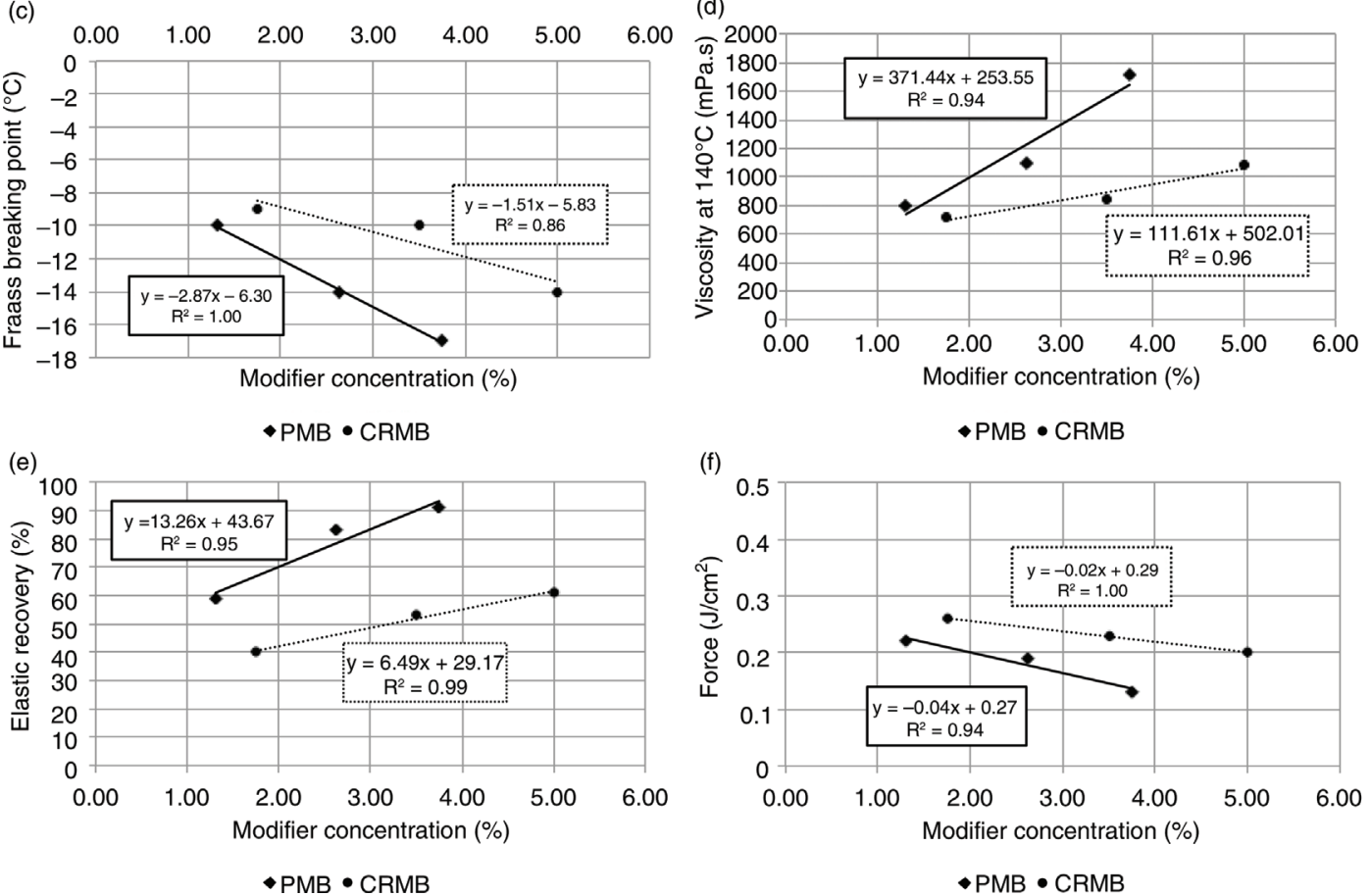

FIgURE 3. Binder properties vs. Modifier concentration: a) Needle penetration; b) Softening point; c) Fraass breaking point; d) Viscosity at $140^{\circ} \mathrm{C}$; e) Elastic recovery and f) Force-ductility.

performance of both modifiers, the same concentration has to be considered. In this way, assuming a concentration of $3 \%$, in Figure $3 \mathrm{a}$ and Figure $3 \mathrm{~b}$ it can be seen that penetration values are similar while the softening point of PMB is higher than that of CRMB, i.e. in order to have the same softening point, the concentration of crumb rubber in the binder has to be higher than the concentration of SBS-polymers.

Figure $3 \mathrm{c}$ and Figure $3 \mathrm{~d}$ display the results of Fraass breaking point and viscosity at $140{ }^{\circ} \mathrm{C}$. As above, assuming a concentration of $3 \%$, it can be observed that CRMB viscosity is lower than PMB, and that in order to have the same breaking point, the concentration of crumb rubber has to be higher. Figure $3 \mathrm{e}$ and Figure $3 \mathrm{f}$ present the results of forceductility and elastic recovery tests. In this case, for an equal concentration of modifier, the force needed in the force-ductility test is higher for CRMB, while its elastic recovery is lower than that of the PMB.
The fact that crumb rubber concentration has to be higher than that of SBS-polymers in order to have similar features is in accordance with the results shown by (1).

\subsubsection{UCL method}

In order to study the performance of both modified binders in terms of cohesion, water sensitivity, thermal and ageing susceptibility, Cantabro losses are compared before and after immersion of the samples and versus temperature and ageing time respectively. These results are shown in Figure 4, 5 and 6.

In Figure 4 and Table 3 it can be observed that reducing in the same amount both modifiers, CRMBs have less Cantabro losses than PMBs, especially after immersion (the increase in losses is lower for CRMBs than for PMBs, see Table 3). This fact means that CRMBs have greater cohesion and less 


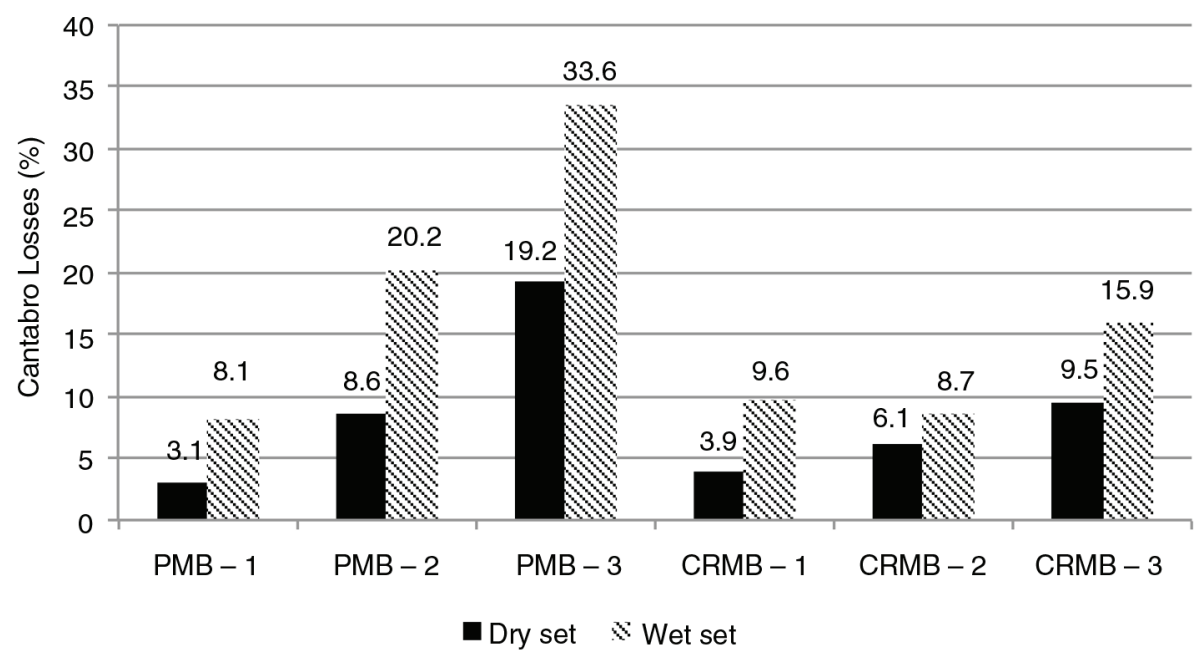

FIGURE 4. Water sensitivity test.

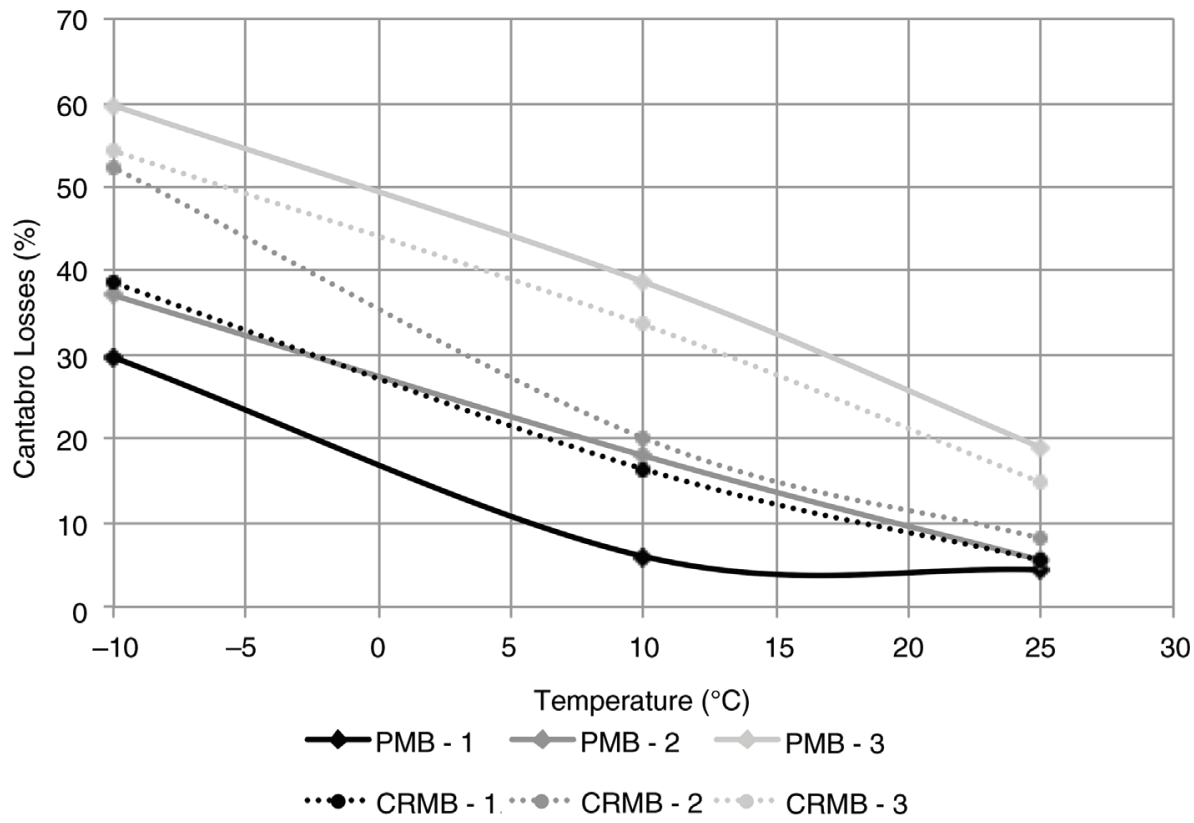

FIGURE 5. Thermal susceptibility results.

water sensitivity than PMBs for the concentration of modifiers studied.

Figure 5 displays the results of the thermal susceptibility tests at $-10{ }^{\circ} \mathrm{C}, 10^{\circ} \mathrm{C}$ and $25^{\circ} \mathrm{C}$ of the six binders. Both types of binders exhibited similar susceptibility to temperature changes due to the analogous slopes and trends of the curves with the reduction of modifiers. In the same way, in Figure 6, the results of the ageing tests gave the same conclusion. In this regard, both CRMBs and PMBs have comparable thermal and ageing susceptibility. It is remarkable that differences in Cantabro losses are greater at low temperature $\left(-10{ }^{\circ} \mathrm{C}\right)$ and intermediate ageing time (4h) regarding changes in modifier concentration.

\subsection{Influence of modifiers concentration}

\subsubsection{Conventional tests}

Figure 3 (a-c) shows the results of binder characterisation. Figure 3 reflects the improvement that the addition of modifiers confer to bitumen: as the concentration of both modifiers increases, modified binders are softer but more elastic, so they would be more resistant to rutting and fatigue; in addition, 


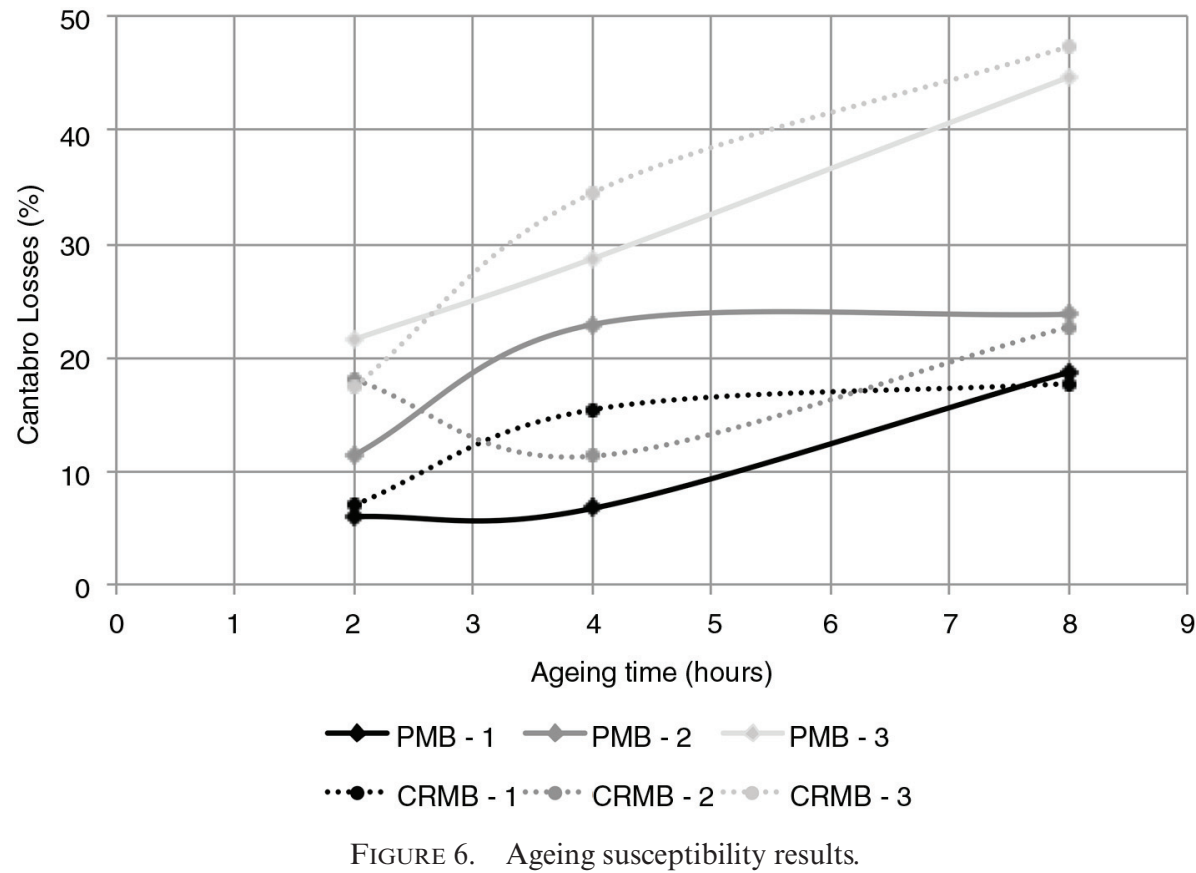

they are able to bear lower temperatures (due to the lower Fraass breaking point), so they would also have more resistance to thermal cracking. Analysing Figure 3 in terms of stability of the binders to modifier concentration and considering the absolute value of the slopes of the trend lines in Figure 3 as a measure of the change of binder properties with the change in modifier content, PMBs are more sensitive to the concentration of additives than CRMBs.

\subsubsection{UCL method}

Cantabro losses before and after immersion in water are displayed in Figure 7 versus modifier concentration. The lower the concentration, the higher the Cantabro losses, showing the improvement that SBS-polymers and crumb rubber produce in binder cohesion and aggregate-binder adhesiveness. In terms of sensitivity to modifier concentration, the decrease of Cantabro losses is higher for PMBs than

TABLE 3. Cantabro losses increase after water immersion (\%)

\begin{tabular}{lc}
\hline Bitumen & $\begin{array}{c}\text { Cantabro losses increase after water } \\
\text { immersion (\%) }\end{array}$ \\
\hline PMB-1 & 161.3 \\
PMB-2 & 134.9 \\
PMB-3 & 75.0 \\
CRMB-1 & 146.2 \\
CRMB-2 & 42.6 \\
CRMB-3 & 67.4 \\
\hline
\end{tabular}

for CRMBs as the concentration increases, this fact is reflected in the slope of the trend lines of Figure 7. Therefore, it can be said that PMBs have a greater sensitivity to changes in modifier concentration than CRMBs in terms of cohesion and after immersion in water.

Figure 8 displays the results of the thermal sensitivity tests. Comparing the behaviour of the two binders, although losses on CRMBs are higher at all the temperatures studied, they change less with the change in modifier concentration, meaning that CRMB has lower susceptibility than PMB to the concentration of modifier at the three temperatures studied and therefore its performance would be more stable to changes in modifier concentration.

Figure 9 shows the results of the ageing resistance tests of the UCL method. As the time of ageing increases, losses of PMB and CRMB tend to enlarge significantly due to the hardening of the binders. Concerning the concentration of additives, in Figure 9 as the amount of SBS-polymers and crumb rubber increases, Cantabro losses are lower so the effect of modifiers enhances mix durability. In addition, in the same way as for thermal sensitivity, CRMBs seem more stable to changes in modifier concentration at the three ageing times studied.

Lastly, the linear relationships for all the properties studied exhibited high goodness of fit values, which suggests that the change in modified binder properties is lineally proportional to the change in modifier concentration within the range of concentrations tested in this investigation. 


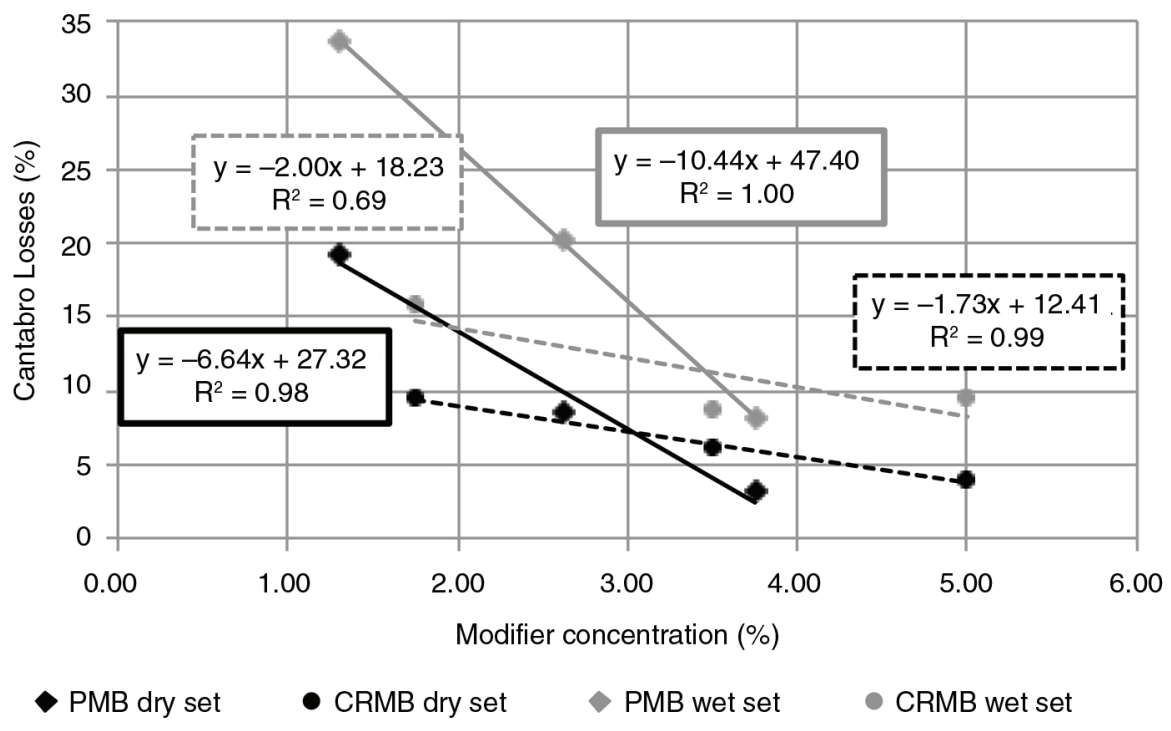

FIGURE 7. Cantabro losses of dry and wet sets vs. modifier concentration.

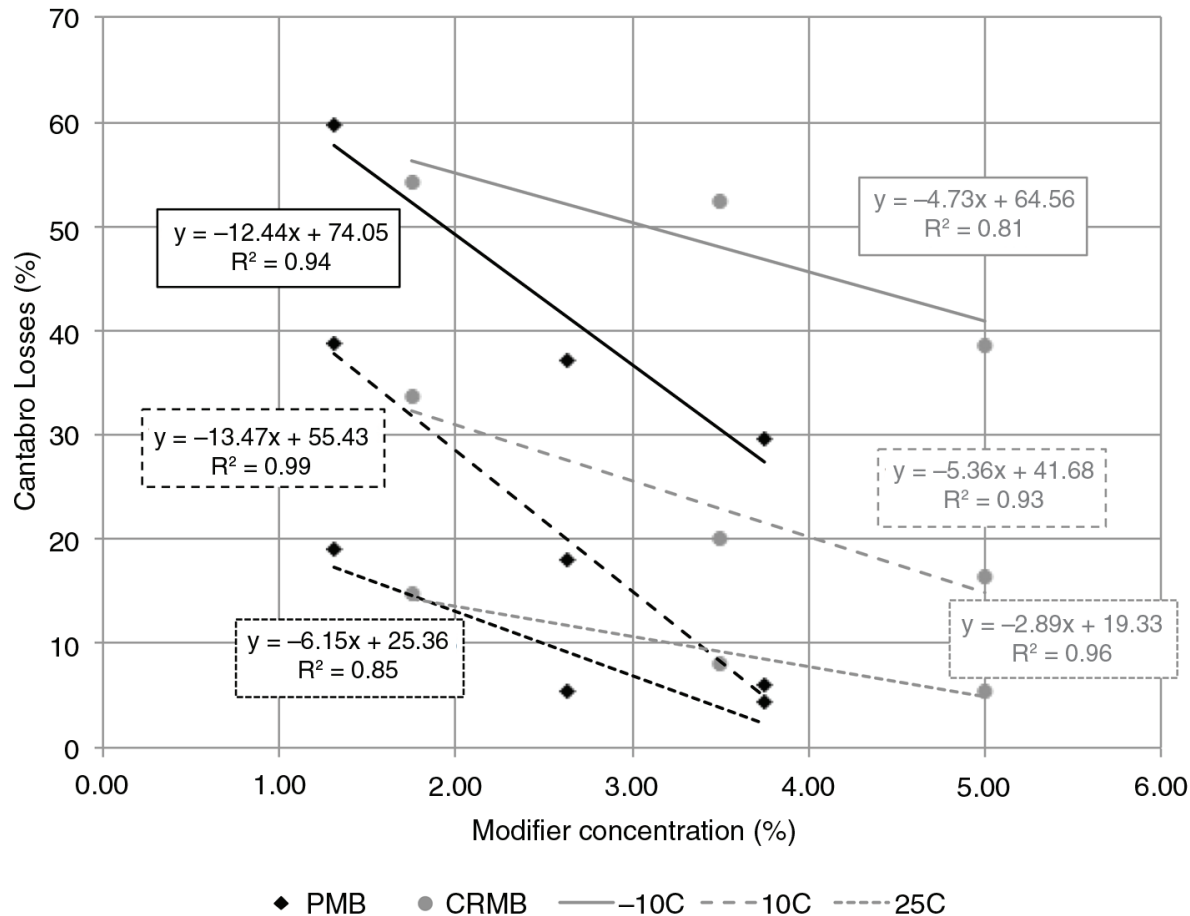

FIGURE 8. Thermal sensitivity vs. modifier concentration.

\section{CONCLUSIONS}

This paper analyses and compares the performance and the influence of additive concentration on three crumb rubber and three SBS-polymer modified binders in terms of their most important properties for pavement engineering. Based on the results of the tests carried out, the following conclusions can be drawn:
- Crumb rubber concentration in the binder has to be higher than that of SBS-polymers in order to obtain a similar performance.

- Crumb rubber modifier binders are more stable than SBS-polymer modified binders in terms of modifier concentration for all the properties studied. This fact can be seen as an advantage in pavement engineering due to the fact that if concentration of the modifier has 


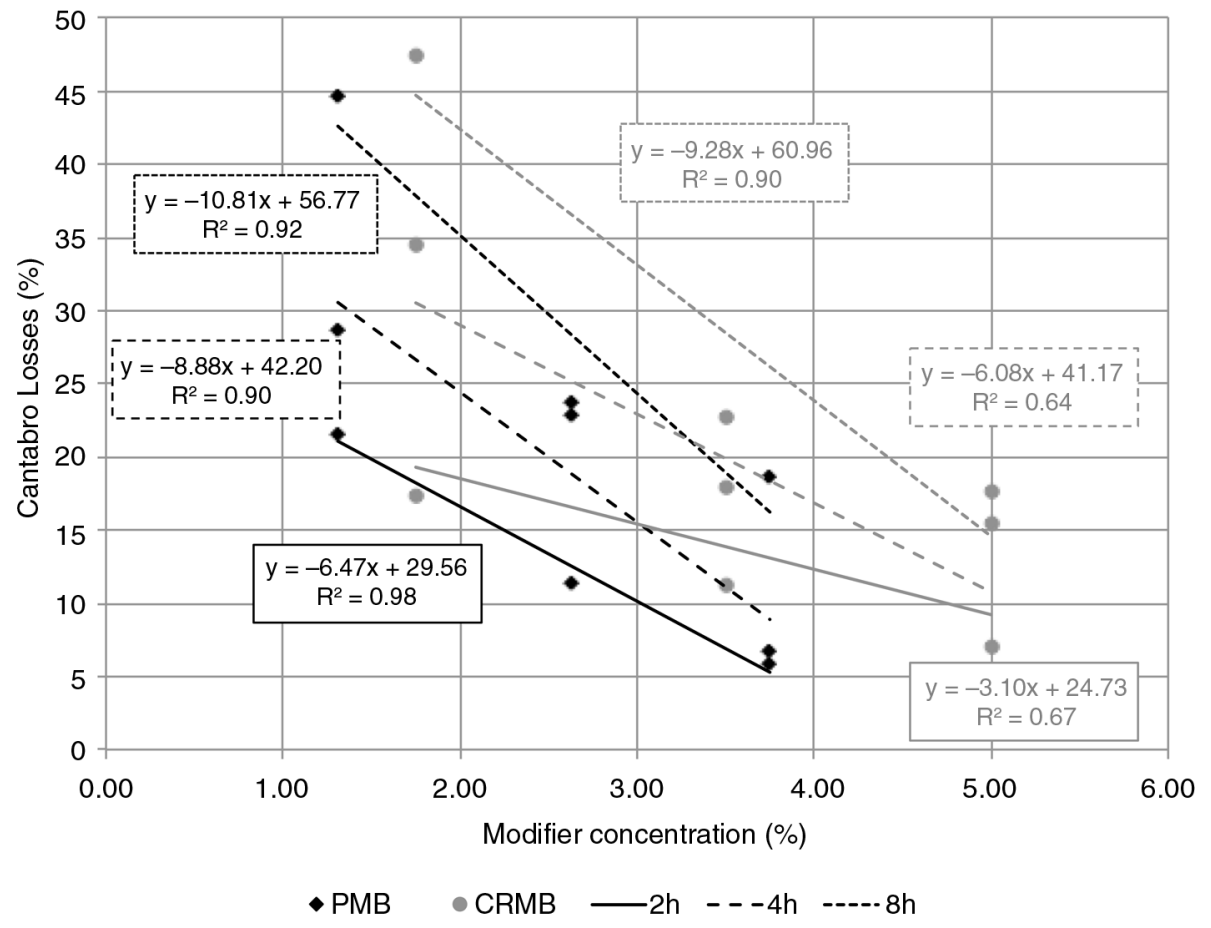

FIGURE 9. Ageing resistance vs. modifier concentration.

to be decreased (implying budget savings), the properties of the binder would change less in the case of CRMB and therefore the expected performance would be better than that of PMB if the concentration of modifiers has to be decreased.

- UCL allowed the analysis of important properties of asphalt binders for pavement engineering. In this sense, crumb rubber binders exhibited less water susceptibility and similar thermal and ageing sensitivity to SBS-polymer modified binders. Thereby, CRMBs are a real alternative to PMBs in terms of performance and with environmental-friendly added value.

- Linear relationships have been found between modifier concentration and the properties studied, which suggest that the change in modified binder properties is lineally proportional to the change in modifier concentration within the range of concentrations tested in this investigation.

\section{ACKNOWLEDGEMENTS}

Authors would like to acknowledge the Agencia Andaluza de la Obra Pública de la Junta de Andalucía, Spain, for the financial support received. These results come from a project that has been financed with resources from the European Regional Development Fund (ERDF).

\section{REFERENCES}

1. Kök, B.V.; Colak, H. (2011) Laboratory comparison of the crumb-rubber and SBS modified bitumen and hot mix asphalt. Constr. Build. Mater. 25, 3204-3212. http://dx.doi. org/10.1016/j.conbuildmat.2011.03.005.

2. Yildirim, Y. (2007) Polymer modified asphalt binders. Constr. Build. Mater. 21, 66-72, http://dx.doi.org/10.1016/j. conbuildmat.2005.07.007.

3. Huang, Y:; Bird, R.N.; Heidrich, O. (2007) A review of the use of recycled solid waste materials in asphalt pavements. Resour. Conserv. Recy. 52, 58-73, http://dx.doi. org/10.1016/j.resconrec.2007.02.002.

4. Moreno, F.; Rubio, M.C.; Martínez-Echeverría, M.J. (2011) Analysis of digestion time and the crumb rubber percentage in dry-process crumb rubber modified hot bituminous mixes. Constr. Build. Mater. 25, 2323-2334. http://dx.doi. org/10.1016/j.conbuildmat.2010.11.029.

5. Navarro, F.J.; Partal, P.; Martínez-Boza, F.; Gallegos, C. (2005) Influence of Crumb Rubber Concentration on the Rheological Behavior of a Crumb Rubber Modified Bitumen. Energ. Fuel. 19, 1984-1990. http://dx.doi.org/ 10.1021/ef049699a.

6. Shen, J; Amirkhanian, S. (2005) The influence of crumb rubber modifier (CRM) microstructures on the high temperature properties of CRM binders. Int. J. Pavement Eng. 4, 265-271. http://dx.doi.org/10.1080/10298430500373336.

7. Lee, S-J.; Akisetty, C.K.; Amirkhanian, S.N. (2008) The effect of crumb rubber modifier (CRM) on the performance properties of rubberized binders in HMA pavements. Constr. Build. Mater. 22, 1368-1376. http://dx.doi. org/10.1016/j.conbuildmat.2007.04.010.

8. Thodesen, C.; Shatanawi, K.; Amirkhanian, S. (2009) Effect of crumb rubber characteristics on crumb rubber modified (CRM) binder viscosity. Constr. Build. Mater. 23, 295-303. http://dx.doi.org/10.1016/j.conbuildmat.2007.12.007.

9. Ali, A.; Mashaan, N.; Karim, M. (2013) Investigations of physical and rheological properties of aged rubberized bitumen. Adv. Mater. Sci. Eng. 2013, 1-8. http://dx.doi.org/ 10.1155/2013/239036. 
10. Pérez, Jiménez, F.; Miró Recasens, R. (1994) New methodology for asphalt binder characterisation: the UCL method. Revista Técnica de la Asociación Española de la Carretera, 73, 27-48.

11. Páez Dueñas, A.; Pérez Jiménez, F.; Miró Recasens, R. (2009) Evaluation of the Cohesion of Crumb Rubber Modified Bitumens by Means of UCL Method. Road Mater. Pavement. 10, 667-676. http://dx.doi.org/10.1080/1 4680629.2009.9690219.

12. Bianchetto, H.; Miró, R.; Pérez-Jiménez, F.; Martínez, A.H. (2007) Effect of Calcareous Fillers on Bituminous Mix Aging. Transport. Res. Rec. 1998, 140-148. http://dx.doi. org/10.3141/1998-17.

13. Miró Recasens, R.; Perez Jimenez, F. (2001) Procedure for the Evaluation of Asphalt Binders Ageing in contact with Aggregates and Application of this Procedure to Analyze the Influence of the Aggregate Type on Binder Ageing. Road Mater. Pavement. 2, 97-110. http://dx.doi.org/10.108 $0 / 14680629.2001 .9689895$

14. AENOR, (2010) UNE-EN 1097-2. Test for mechanical and physical properties of aggregates. Part 2: Method for the determination of resistance to fragmentation, Asociación Española de Normalización y Certificación, (in Spanish), On line at: https://www.aenor.es/aenor/normas/normas/ fichanorma $\cdot$ asp?codigo $=$ N0046026\&tipo $=\mathrm{N} \& \mathrm{pag}=\mathrm{pag}$ ina per buscador.asp\#.Ut q0RC0rIU.

15. AENOR, (2001) UNE-EN 1097-6. Test for mechanical and physical properties of aggregates. Part 2: Method of particle density and water absorption, Asociación Española de Normalización y Certificación, (in Spanish), On line at: https://www.aenor.es/aenor/normas/normas/fichanorma. asp? codigo $=\mathrm{N} 0025079 \& \mathrm{tipo}=\mathrm{N} \& \mathrm{pag}=$ pagina_per_busca dor.asp\#.Ut_rgRCOrIU.

16. AENOR, (2012) UNE-EN 12697-6. Bituminous mixtures. Test methods for hot mix asphalt. Part 8: Determination of bulk density of bituminous specimens, Asociación Española de Normalización y Certificación, (in Spanish), On line at: https://www.aenor.es/aenor/normas/normas/fichanorma.asp $?$ codigo $=\mathrm{N} 0049868 \&$ tipo $=\mathrm{N} \&$ pag $=$ pagina_per_buscador. asp\#.Ut_tgBCOrIU.

17. AENOR, (2003) UNE-EN 12697-8. Bituminous mixtures. Test methods for hot mix asphalt. Part 8: Determination of void characteristics of bituminous specimens, Asociación Española de Normalización y Certificación, (in Spanish), On line at: https://www.aenor.es/aenor/normas/normas/ fichanorma $\cdot a$ asp $\operatorname{codigo}_{\mathrm{o}}=\mathrm{N} 0030158 \&$ tipo $=\mathrm{N} \& \mathrm{pag}=\mathrm{pag}$ ina per buscador.asp\#.Ut_tohC0rIU.

18. AENOR, (2007) UNE-EN 1426. Bitumen and bituminous binders. Determination of needle penetration, Asociación Española de Normalización y Certificación, (in Spanish), On line at: https://www.aenor.es/aenor/normas/normas/ fichanorma $\cdot$ asp? $\operatorname{codigo}=$ N0039237\&tipo $=\mathrm{N} \& \mathrm{pag}=\mathrm{pag}$ ina_per_buscador.asp\#.Ut_rxRCOrIU.

19. $\mathrm{AENO} \overline{\mathrm{R}}$, (2007) UNE-EN 1427. Bitumen and bituminous binders. Determination of softening point, Asociación Española de Normalización y Certificación, (in Spanish), On line at: https://www.aenor.es/aenor/normas/normas/ fichanorma $\cdot$ asp? $\operatorname{codigo}=\mathrm{N} 0039238 \&$ tipo $=\mathrm{N} \& \mathrm{pag}=\mathrm{pag}$ ina_per_buscador.asp\#.Ut_r7hC0rIU.

20. AENOR, (2007) UNE-EN 12593. Bitumen and bituminous binders. Determination of the Fraass breaking point, Asociación Española de Normalización y Certificación, (in Spanish), On line at: https://www.aenor.es/aenor/normas/ normas/fichanorma.asp?codigo $=$ N0039089\&tipo $=$ N\&pag =pagina_per_buscador.asp\#.Ut_tXhCOrIU.

21. AENOR, (2010) UNE-EN 13398. Bitumen and bituminous binders. Determination of elastic recovery of modified bitumens, Asociación Española de Normalización y Certificación, (in Spanish), On line at: https://www. aenor.es/aenor/normas/normas/fichanorma.asp?codigo $=\mathrm{N} 0046228 \&$ tipo $=\mathrm{N} \&$ pag=pagina_per_buscador.asp\#. Ut_txxC0rIU.

22. AENOR, (2008) UNE-EN 13589. Bitumen and bituminous binders. Determination of the tensile properties of modified bitumen by the force ductility method, Asociación Española de Normalización y Certificación, (in Spanish), On line at: https://www.aenor.es/aenor/normas/normas/fichanorma. asp? $\operatorname{codigo}=\mathrm{N} 0042439 \&$ tipo $=\mathrm{N} \& \mathrm{pag}=$ pagina_per_buscador.asp\#.Ut_t8RCOrIU.

23. MOPT, (1992) NLT 352/00 Caracterización de mezclas bituminosas abiertas por medio de ensayo cántabro de pérdida por desgaste. Ensayos de carreteras, Ministerio de Obras Públicas y Transportes, (in Spanish), On line at: http://www. carreteros.org/normativa/otros/nlt/pdfs/rosas/2000/352_00. pdf.

24. MOPT, (1992) NLT 159/00 Resistencia a la deformación plástica de mezclas bituminosas empleando el aparato Marshall. Ensayos de carreteras, Ministerio de Obras Públicas y Transportes, (in Spanish), On line at: http://www.carreteros. org/normativa/otros/nlt/pdfs/rosas/2000/159_00.pdf. 